\title{
$\mathrm{VOF}$ 법과 $\mathrm{DEM}$ 에 의한 사석구조물 변형예측모델과 그 적용성에 관한 연구
}

\author{
김미금 $*+$ 김창제 \\ *한국선급 에너지환경사업단, † 한국해양대학교 항해학부 교수
}

\section{A Study for Analysis on Deformation of Rubble Mound Structure Using VOF and DEM Methods}

\author{
Mi-Kum Kim* • + Chang-Je Kim \\ *Energy \& Environmental Business Center, Korean Register of Shipping, Daejeon 305-343, Korea \\ † Division of Navigation Science, National Korea Maritime University, Busan 606-791, Korea
}

\begin{abstract}
요 약 : 사석 방파제와 같은 불연속 구조물의 안정 해석이 수행되었다. 파랑장의 계산에는 CADMAS-SURF를 이용하고 마운드의 변형 해 석에는 개별요소법을 이용하였다. 파랑장과 구조물 변형과의 상호작용을 고려하였고, 마운드를 구성하는 요소의 다양성에서 비롯되는 물성치 들을 고려하기 위해 스프링계수, 점성, 마찰계수를 몬테카를로법에 의해 랜덤하게 입력하였다. 또한 수치해석 결과를 검증하고 해석 모델의 타 당성을 검토하기 위해 모형실험을 실시했다. 모형실험에서는 마운드를 구성하는 요소로써 유리구를 이용했고, 실험결과와의 비교를 위하여 요 소의 크기를 수치해석의 모델요소와 일치시켰다. 그 결과 수치해석결과와 모형실험결과가 정성적으로 일치했으며, 본 해석 모델의 타당성이 검 증되었다.
\end{abstract}

핵심용어 : CADMAS-SURF, 개별요소법, 사석 방파제, 접촉강성, 몬테카를로법

\begin{abstract}
A numerical model, which can compute deformation of rubble mound structures composed with various size materials, was proposed. In the numerical model, wave field into the mound structures was computed by CADMAS-SURF and the deformations of mound structures were computed by DEM. Interaction between wave field and sectional deformation of structure was considered and to present the variation of behaviors caused by various properties of materials, computation was carried out with random coefficients by Monte Carlo simulation method for contact stiffness and friction angle. The experiments were carried out with rubbles and glass balls with radius of $2.9 \mathrm{~cm}, 2.6 \mathrm{~cm}$ and $1.5 \mathrm{~cm}$. And the deformation characteristics of rubble mounds composed with various size materials were clarified. Furthermore the validity and the applicability of the model were discussed by comparing with the experimental results.
\end{abstract}

Key words : CADMAS-SURF, DEM, Rubble mound, Contact stiffness, Monte Carlo simulation

\section{1. 서 론}

거석을 쌓아올려 방파제로써 파랑을 제어토록 하는 방법은 사석제 또는 경사제로 불리며 예전부터 이용되어온 방식으로 방파제의 원형이라고 불리기도 하며, 현재에도 많이 이용되는 방식이다. 특히, 지형의 형상에 구애받지 않고 시공할 수 있다 는 점, 반사파를 저감시켜 주변해역을 항행하는 선박에 악영향 을 미치지 않는다는 점, 붕괴나 변형 등의 손괴가 발생해도 전 면파괴에까지 도달하지 않고 유지보수가 용이하다는 점에서 외 국에서는 방파제의 주류를 이루고 있는 경우도 있다(椹木, 1991).

최근 경관의 관점에서 우수하다는 이유로 사석 등의 재료를 이용해 투과성 잠제를 시공하는 사례가 증가하고 있으나, 사석
등을 이용해 잠제를 시공하는 경우에 잠제의 안정성을 확보하 는 것이 중요한 요소가 된다. 특히, 반복해서 내습하는 고파랑 에 의한 잠제의 파괴를 방지하기 위해서는 각각의 사석간의 충 돌과 간섭, 그리고 사석의 움직임과 파동장의 상호작용을 고려 해 파력에 의한 구조물의 거동을 정확히 예측할 필요가 있다. 사석 등에 의한 투과성 잠제의 침하나 블록과 같은 피복재의 전도 등에 의한 단면변형해석에 있어서 Cundall(1971)에 의해 제안된 개별요소법(DEM)을 이용한 해석이 행해지고 있다(藤井 등, 2001 ; 荒木, 2003 ; 高山, 2006). 김 등(2007)은 혼합입경 요소로 구성되는 사석구조물에 대해서 $\mathrm{VOF}$ 법과 $\mathrm{DEM}$ 에 의한 변형해석 모델을 제안했으나, 실험결과와의 비교가 충분하지 않았고, 모델에 포함되어 있는 파라메터의 설정방법과 적용성 이 충분히 검토되지 않았다. 본 연구에서는 모형실험에 의해 혼

\footnotetext{
* 연회원, kimmk@krs.co.kr 042)869-9514
}

† 종신회원, kimc@hhu.ac.kr 051)410-4226 
합입경요소로 구성된 마운드의 변형특성에 관해 파악함과 동시 에, 수치해석결과와 모형실험결과를 비교함으로써 모델의 적용 성을 검토하고 각종 파라메타의 설정방법 등을 검토했다.

\section{2. 모형실험}

\section{1 실험방법 및 실험조건}

모형실험에 이용한 입자의 중량은 허드슨 공식에 의해 계산 했다. 이 때, 비중으로는 유리의 평균비중인 2.5 를, 파고는 $12 \mathrm{~cm}$, 사면의 구배는 30도, 안정계수는 수리공식집(日本土木學 會, 1985)을 참고로 10 으로 했다. 그 결과를 기초로 평균입경 $2 \mathrm{~cm}$ 의 사석으로 구성된 마운드와 $2.9 \mathrm{~cm}$ 와 $2.6 \mathrm{~cm}, 2.6 \mathrm{~cm}$ 와 $1.5 \mathrm{~cm}$ 의 혼합입경의 유리구로 구성된 세 종류의 마운드를 대상 으로 실험을 실시했다.

Fig. 1의 상부는 실험장치의 개요를, 하부는 그 상세를 나타 낸다. 실험에 이용된 조파수조는 길이 $25 \mathrm{~m}$, 폭 $0.5 \mathrm{~m}$, 높이 $0.6 \mathrm{~m}$ 로 수로의 한쪽에는 조파기가 반대편에 소파장치가 설치되어 있다. 또한 횡단방향의 영향을 가능한 한 줄이기 위해 수로의 중앙에 격벽을 설치하여 마운드 모형을 설치하는 수로의 폭을 $15 \mathrm{~cm}$ 가 되도록 제작했다. 마운드는 하부길이 $100 \mathrm{~cm}$, 높이 $20 \mathrm{~cm}$, 천단길이 $20 \mathrm{~cm}$, 폭 $15 \mathrm{~cm}$ 규모로 설치했다. 마운드 하부 에는 평균입경 $1 \mathrm{~cm}$ 의 사석을 이용해 해저지반을 시공, 마운드 요소의 침하를 표현하고 요소의 운동에 마찰이 작용하도록 구 성 했다. 수심과 유체력의 관계를 조사하기 위해 각각의 마운드
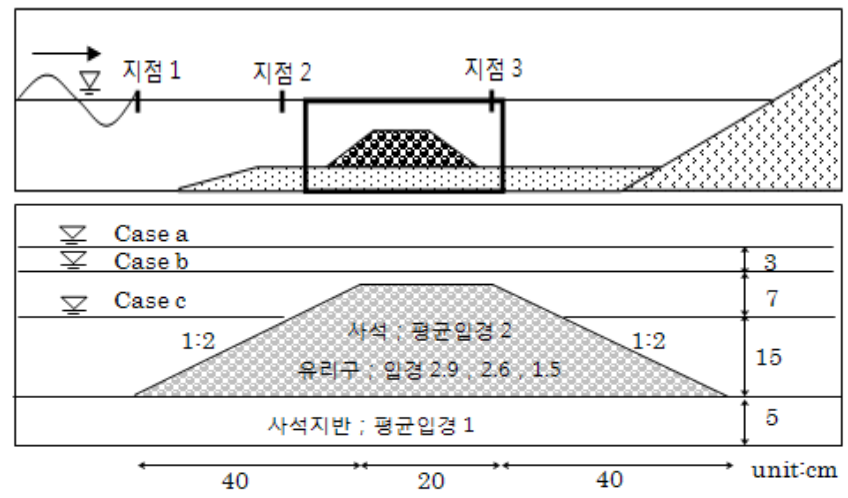

Fig. 1 Outline of setup for experiment

Table 1 Experiment condition

\begin{tabular}{|c|c|c|c|c|c|c|}
\hline \multirow{2}{*}{ Case } & \multicolumn{2}{|c|}{1} & \multicolumn{2}{|c|}{2} & \multicolumn{2}{|c|}{3} \\
\hline & $\mathrm{a}$ & b & $\mathrm{a}$ & b & $\mathrm{a}$ & b \\
\hline 천단수심 $(\mathrm{cm})$ & 5 & 2 & 5 & 2 & 5 & 2 \\
\hline $\begin{array}{c}\text { 파고 }(\mathrm{cm}), \\
\text { 주기 }(\mathrm{s})\end{array}$ & $\begin{array}{c}11.8 \\
1.2\end{array}$ & $\begin{array}{c}11.7 \\
1.2\end{array}$ & $\begin{array}{c}14.5 \\
1.2\end{array}$ & $\begin{array}{c}12.0 \\
1.2\end{array}$ & $\begin{array}{c}13.8 \\
1.2\end{array}$ & $\begin{array}{c}11.4 \\
1.2\end{array}$ \\
\hline 재료와 입경 & \multicolumn{2}{|c|}{$\begin{array}{c}\text { 사석 } \\
\text { (평균입 경 } \\
2 \mathrm{~cm} \text { ) }\end{array}$} & \multicolumn{2}{|c|}{$\begin{array}{c}\text { 유리구 } \\
(2.9 \mathrm{~cm} \text {, } \\
2.6 \mathrm{~cm})\end{array}$} & \multicolumn{2}{|c|}{$\begin{array}{c}\text { 유리구 } \\
(2.6 \mathrm{~cm} \text {, } \\
1.5 \mathrm{~cm})\end{array}$} \\
\hline 측정시간 & \multicolumn{6}{|c|}{3 분 } \\
\hline
\end{tabular}

에 대해서 천단수심 $5 \mathrm{~cm}$ (수심 $25 \mathrm{~cm}$ )와 $2 \mathrm{~cm}$ (수심 $22 \mathrm{~cm}$ )의 두 경우에 대해 실험을 실시했다. 마운드 모형의 설정조건, 천단수 심 및 파랑조건 등의 실험조건을 Table 1 에 나타낸다. 마운드 의 전후방에 용량식 파고계를 설치하여, 마운드 통과 전과 통과 후의 수면파형을 측정하고 파고 및 주기를 산정했다.

\section{1 실험결과}

Fig.2 및 Fig.3은 천단수심 $5 \mathrm{~cm}$ 에서 조파개시 후 20초간의 마운드 전후방의 수면형상 측정결과와 마운드 변형결과를 나타 낸 것이다. Case 1 의 결과를 보면, 마운드로부터 $2 \mathrm{~m}$ 떨어진 지 점1에서는 평균파고 $11.8 \mathrm{~cm}$ 이었으나 마운드 통과 직후인 지점 2 에서는 평균파고 $11.9 \mathrm{~cm}$, 지점 3 에서는 쇄파의 영향으로 평균 파고 $7.95 \mathrm{~cm}$ 로 변화되었다. 그리고 Case 2 의 경우는, 지점1에서 는 평균파고 $11.16 \mathrm{~cm}$, 지점 2 에서는 평균파고 $12.5 \mathrm{~cm}$, 지점 3 에 서는 평균파고 $8.8 \mathrm{~cm}$ 로 변화했다. 또한 Case 3 의 경우에는, 지 점 1 에서는 평균파고 $13.84 \mathrm{~cm}$ 이었으나 지점 2 에서는 $12.57 \mathrm{~cm}$, 마운드 통과후인 지점 3 에서는 $9.23 \mathrm{~cm}$ 로 감소했다.

Fig. 3의 Case 1을 보면 약간이지만 마운드 전방 상부의 사석 이 후방 쪽으로 이동하여 사면 상에 퇴적되어 있는 것을 알 수 있다. 그러나 Case 2 의 경우에는 전방 측 마운드 상부요소의 파 랑에 의한 움직임을 보이며 불안정한 상태를 보였으나 단면의 변형에 까지는 이르지 않았다. Case 3에서는 전후방의 마운드 상부의 요소가 후방측 하부에 퇴적되어 있는 것을 볼 수 있다. 후방 상부의 침식이 더 많이 진행된 것을 알 수 있는데, Fig 3, $\mathrm{c}$ 의 우측 상부에서 보이는 바와 같이 파랑이 마운드를 통과하 면서 강한 난류가 형성되어 입자에 큰 힘이 작용한 것으로 판 단된다.

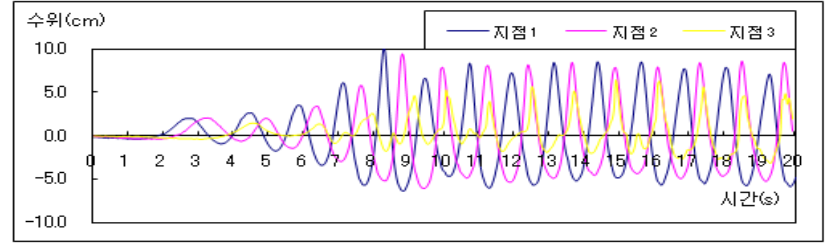

a) Case 1

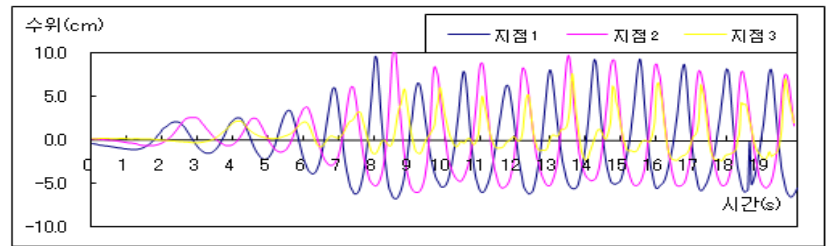

b) Case 2

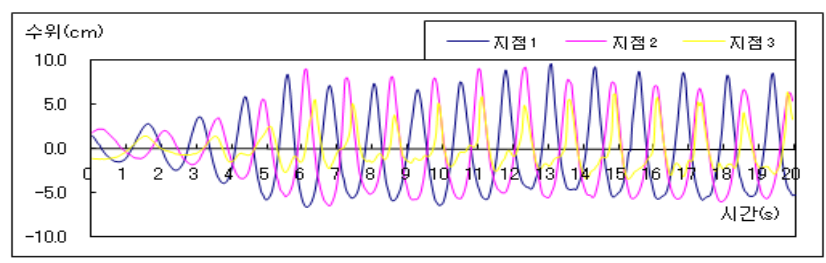

c) Case 3

Fig. 2 Time series of wave height(Case a) 


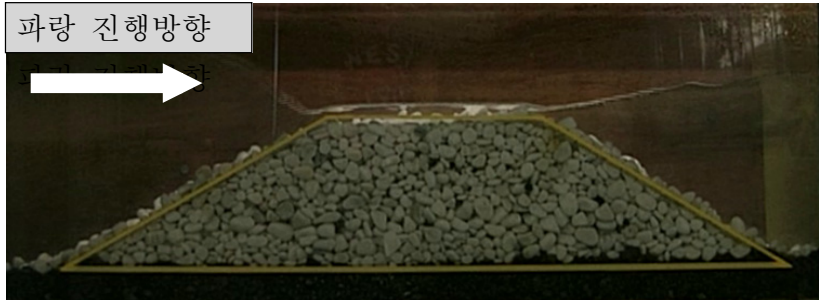

a) Case 1

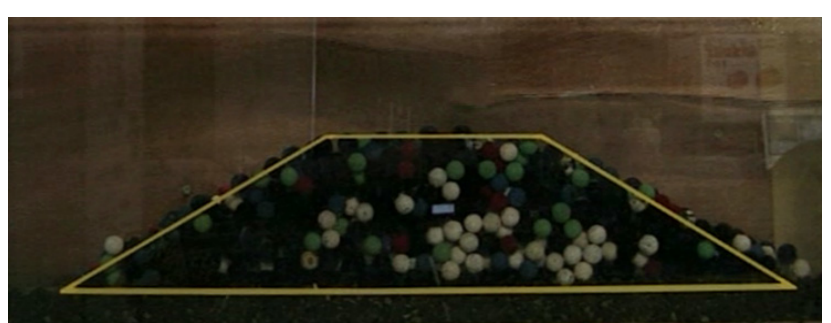

b) Case 2

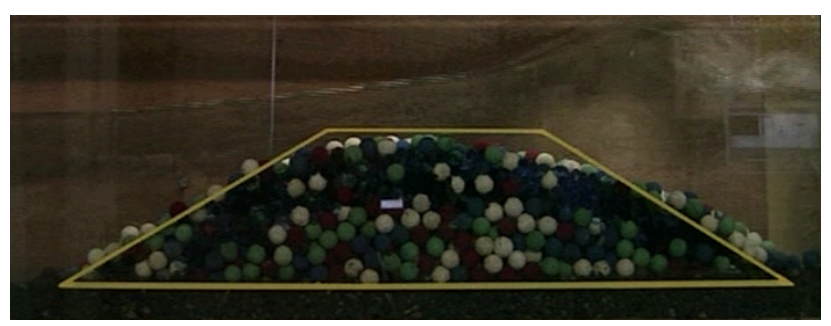

c) Case 3

Fig. 3 Deformed section by wave(Case a)

Fig. 4 및 Fig. 5는 천단수심 $2 \mathrm{~cm}$ 에서의 수면형상의 측정결 과와 마운드 변형 결과를 나타낸 것이다. Case 1 의 경우, 지점 1 에서는 평균파고 $11.65 \mathrm{~cm}$ 이었으나 지점 2 에서는 평균파고 $12.44 \mathrm{~cm}$, 지점 3 에서는 파고가 감소되어 평균파고 $6.97 \mathrm{~cm}$ 로 나 타났다. 그리고 Case 2 의 경우에는, 지점 1 에서는 평균파고 $12.04 \mathrm{~cm}$ 이었으나 지점 2 에서는 $13.03 \mathrm{~cm}$, 지점 3 에서는 파고가 감쇄되어 평균파고 $8.52 \mathrm{~cm}$ 로 계측되었다. 또한 Case 3 의 경우 에는, 지점 1 에서는 $11.4 \mathrm{~cm}$, 지점 2 에서는 사석지반에 의한 수 심의 감소와 마운드 사면에서 발생한 반사파의 영향으로 파형 이 변화되어 평균파고 $12.0 \mathrm{~cm}$ 로, 지점 3 에서는 $6.68 \mathrm{~cm}$ 로 계측 되었다.

마운드 변형 결과를 보면, Case 1 은 마운드 전방 상부의 요소 가 후방으로 이동하여 후방의 사면상에 퇴적된 것을 볼 수 있 다. 또한, Fig.3의 a)에 비해서 이동된 사석의 수가 증가된 것을 알 수 있다. Case 2의 경우에는, 약간의 상부 마운드 요소가 파랑 진행방향을 따라 이동했으나 단면 변형에 까지는 이르지 않았다. Case 3을 보면 전방의 마운드 상부의 요소가 후방으로 이동해서 마운드 하부에 퇴적되었다. 마운드 후방에서의 난류 발생 및 이에 의한 침식이 있었으나 그 영향이 비교적 약하고, 전방으로부터 침식되어 운반된 요소의 퇴적작용이 더욱 활발해 결과적으로는 전방 상부의 침식과 후방 사면부에의 퇴적이라는 결과가 나타났으며. Fig.3의 단면변형 형태와는 반대의 결과가 발생했다.

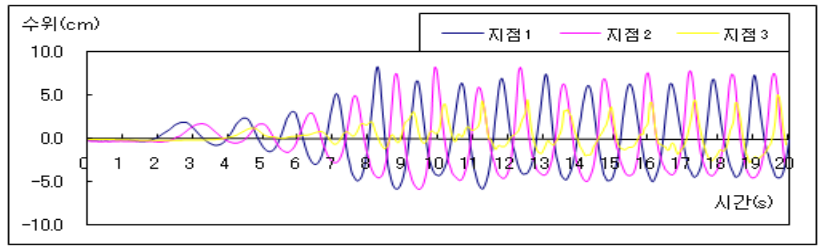

a) Case 1

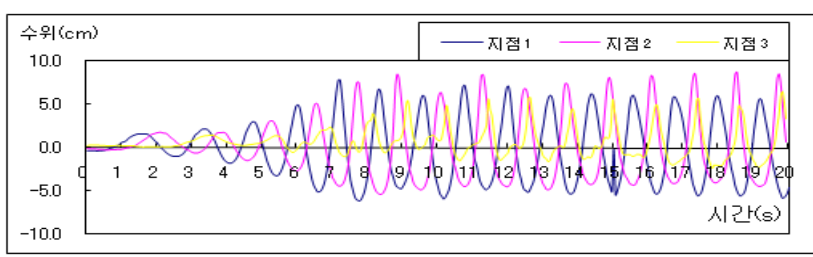

b) Case 2

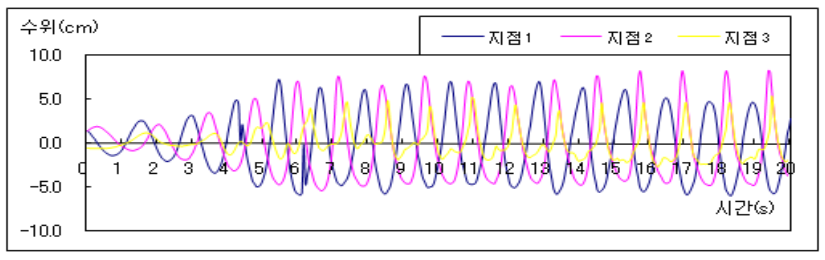

c) Case 3

Fig. 4 Time series of wave height(Case b)

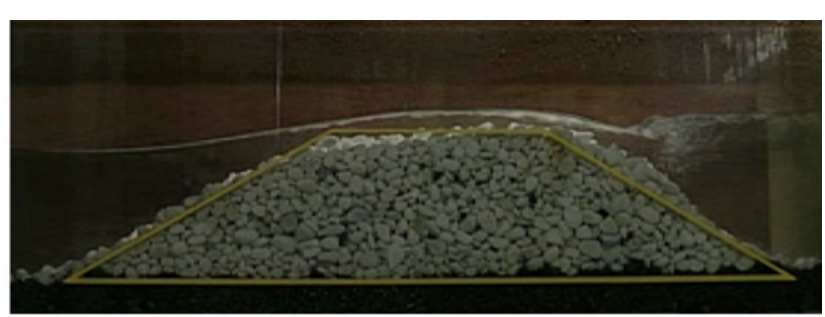

a) Case 1

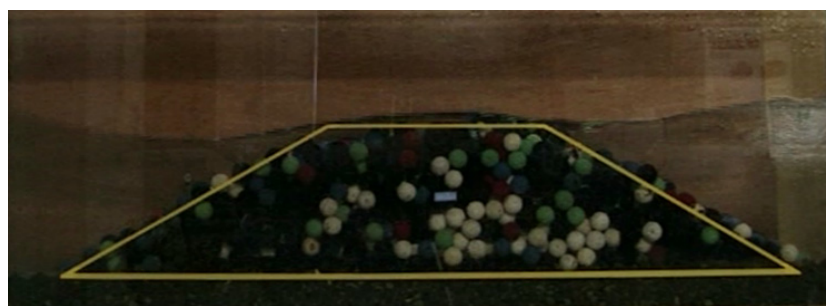

b) Case 2

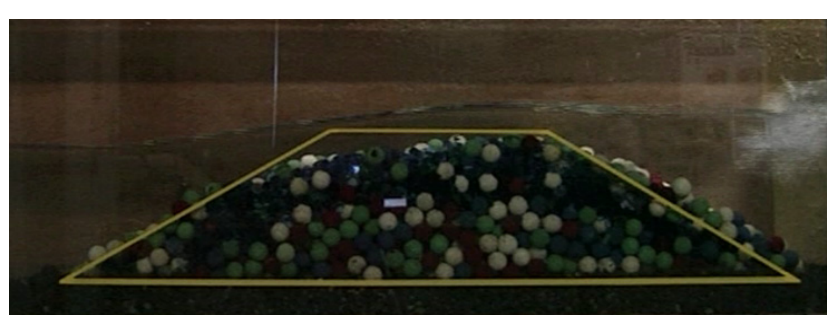

c) Case 3

Fig. 5 Deformed section by wave(Case b)

Fig.6은 마운드의 구성에 따른 파랑감쇄율을 나타낸 것으로, 마운드의 구성에 따라 감쇄율이 상이한 것을 알 수 있다. 두 경 우 모두 Case 3 의 경우 감쇄율이 가장 크게 나타났다. 


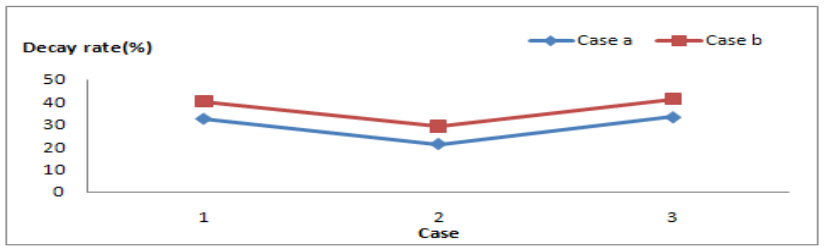

Fig. 6 Decay rates by component of mounds

\section{3. 수치계산모델}

\section{1 수치해석 모델의 개요}

\subsection{1 파동장의 해석}

파동장의 계산에는 자유표면을 비교적 잘 재현할 수 있는 Hirt 등(1981)에 의해 제안된 $\mathrm{VOF}$ 법을 기반으로 개발된 CADMAS$\mathrm{SURF}$ 을 이용한다. 해안역에 있어서의 파동장의 해석에는 해저 사면이나 투과성 소파 구조물 등의 복잡한 형상을 취급하는 것 이 필수요건이 된다. 이를 위해 CADMAS-SURF의 기초방정 식은 2 차원 비압축성 점성유체를 대상으로 한 연속방정식 및 Navier-Stokes방정식을 다공질 모델에 근거해 확장한 식 (1)-(3)이 된다.

$$
\text { 연속방정식 : } \frac{\partial \gamma_{x} u}{\partial x}+\frac{\partial \gamma_{z} w}{\partial z}=S_{p}
$$

운동방정식 :

$$
\begin{array}{r}
\lambda_{\nu} \frac{\partial u}{\partial t}+\frac{\partial \lambda_{x} u u}{\partial x}+\frac{\partial \lambda_{z} w u}{\partial z}=-\frac{\gamma_{\nu}}{\rho} \frac{\partial p}{\partial x}+\frac{\partial}{\partial x}\left\{\gamma_{x} \nu_{e}\left(2 \frac{\partial u}{\partial x}\right)\right\} \\
+\frac{\partial}{\partial z}\left\{\gamma_{z} \nu_{e}\left(\frac{\partial u}{\partial z}+\frac{\partial w}{\partial x}\right)\right\}-D_{x} u+S_{u}-R_{x} \\
\lambda_{\nu} \frac{\partial w}{\partial t}+\frac{\partial \lambda_{x} u w}{\partial x}+\frac{\partial \lambda_{z} w w}{\partial z}=-\frac{\gamma_{\nu}}{\rho} \frac{\partial p}{\partial z}+\frac{\partial}{\partial x}\left\{\gamma_{x} \nu_{e}\left(2 \frac{\partial w}{\partial x}+\frac{\partial u}{\partial z}\right)\right\} \\
+\frac{\partial}{\partial z}\left\{\gamma_{z} \nu_{e}\left(2 \frac{\partial w}{\partial z}\right)\right\}-D_{z} w+S_{w}-R_{z}-\gamma_{\nu} g
\end{array}
$$

여기서, $t$ 는 시간, $x, z$ 는 수평, 연직 좌표, $u, w$ 는 유속의 수 평, 연직성분, $\rho$ 는 밀도, $p$ 는 압력, $\nu_{e}$ 분자 동점성 계수와 소 용돌이 점성계수의 합, $g$ 는 중력 가속도, $\gamma_{\nu}$ 는 공극률 , $\gamma_{x}, \gamma_{z}$ 는 수평, 연직방향의 면적투과율이다. $\lambda_{\nu}, \lambda_{x}, \lambda_{z}$ 는 $C_{M}$ 을 관성 력계수로 하면 식 (4)와 같이 표현되며, 우변 제 2항이 구조물 로부터 받는 관성력의 효과가 된다.

$$
\begin{aligned}
& \lambda_{\nu}=\gamma_{\nu}+\left(1-\gamma_{\nu}\right) C_{M} \\
& \lambda_{x}=\gamma_{x}+\left(1-\gamma_{x}\right) C_{M} \\
& \lambda_{z}=\gamma_{z}+\left(1-\gamma_{z}\right) C_{M}
\end{aligned}
$$

$D_{x}, D_{z}$ 는 에너지 감쇄대를 위한 계수, $S_{p}, S_{u}, S_{w}$ 는 조파 소스 를 위한 소스항이다. 또한, 다공질체로부터의 저항력 $R_{x}, R_{z}$ 는 다음과 같이 유속의 2승에 비례하는 형태로 모델화 된다.

$$
\begin{aligned}
& R_{x}=\frac{1}{2} \frac{C_{D}}{\Delta x}\left(1-\gamma_{x}\right) u \sqrt{u^{2}+w^{2}} \\
& R_{z}=\frac{1}{2} \frac{C_{D}}{\Delta z}\left(1-\gamma_{z}\right) w \sqrt{u^{2}+w^{2}}
\end{aligned}
$$

$C_{D}$ 는 항력 계수, $\triangle x, \triangle z$ 는 $x, z$ 방향의 격자 간격이다.

\section{1 .2 입상체해석}

입상체의 계산에는 Cundall(1971)에 의해 제안된 DEM을 이용 한다.

두 개의 암괴가 충돌 혹은 접촉할 때, 암괴는 탄성체가 아니 고, 접촉점 부근에서 국부적인 소성변형 혹은 파손이 생기므로 완전탄성충돌은 되지 않는다. 본 모델에서는 암석을 강체로 보 고 암괴가 가진 탄성, 비탄성적 성질은 접점 간에 투입한 탄성 스프링(탄성계수 $K$ )과 점성 데시포트(점성계수 $\eta$ )로 표현한다. 이 때 두 개의 암괴(질량 $m$, 관성 모멘트 $I$ )에 주목하면, 병진 $(X)$ 및 회전 $(\phi)$ 에 관한 운동방정식은 다음 식으로 표현된다.

$$
\begin{aligned}
& m \ddot{X}+\eta \dot{X}+K X=0 \\
& \ddot{I}+\eta r^{2} \dot{\phi}+K r^{2} \phi=0
\end{aligned}
$$

이것은 감쇄진동을 나타내며, 주어진 모든 암괴에 대해서 동 일한 운동방정식을 연립해서 푸는 것에 의해 운동 상태에서 정 지 상태에 이르는 암괴의 거동을 해석할 수 있다. 식(7)과 식(8) 을 시간증분 $\triangle t$ 에 의해 차분 근사함과 동시에 미지변위 $X$ 와 $\phi$ (직접적으로는 가속도 $\ddot{X}$ 와 $\ddot{\phi}$ )을 양으로 포함하는 형태로 근사 하는 축차해법으로 계산한다. $X$ 에 관해 그것을 나타내면 식 (7)을 변형해서

$$
m[\ddot{X}]_{t}=-\eta[\dot{X}]_{t-\Delta t}-K[X]_{t-\Delta t}
$$

로 놓고 새로운 가속도 $[\ddot{X}]_{t}$ (이것을 수치적분해서 새로운 변위 $[X]_{t}$ 를 구한다)를 전회의 변위 $[X]_{t-\Delta t}$ 에 기초한 접촉시의 작용력(우변)의 양관수로 보고 축차 계산하는 방법이다.

\subsection{3 $\mathrm{VOF}$ 법과 $\mathrm{DEM}$ 의 연성}

입상체를 구성하는 개별요소를 원주체로 가정했을 때 유동장 내에서의 입상체의 운동은 식(10) 식(12)과 같이 표현된다.

$$
\begin{aligned}
& \left(M_{i}+M_{i}^{\prime}\right) \ddot{x}=\sum_{j}\left[F_{x}\right]_{i j}+\left[f_{x}\right]_{i} \\
& \left(M_{i}+M_{i}^{\prime}\right) \ddot{z}=\sum_{j}\left[F_{z}\right]_{i j}+\left[f_{z}\right]_{i}+v_{i}\left(\rho_{p}-\rho\right) g \\
& \left(\phi_{i}+\phi_{i}^{\prime}\right) \ddot{\omega}=\sum_{j}\left[M_{x}\right]_{i j}
\end{aligned}
$$

여기서, $M_{i}, M_{i}^{\prime}$ 은 요소 $i$ 의 질량 및 부가질량, $\ddot{x}, \ddot{z}$ 는 요소 $i$ 의 $x, z$ 축방향의 가속도 성분 , $\left[F_{x}\right]_{i j},\left[F_{z}\right]_{i j}$ 는 요소 $i$ 에 접 
촉하고 있는 요소 $j$ 로부터 받는 요소간 작용력의 $x, z$ 방향 성분, $\left[f_{x}\right]_{i},\left[f_{z}\right]_{i}$ 는 요소 $i$ 에 작용하는 파력의 $x, z$ 방향 성분 으로 모리슨 식으로 계산한다. 또한 $I_{i}, I_{i}^{\prime}$ 는 요소 $i$ 의 관성 모 멘트 및 부가 관성 모멘트, $\tilde{\omega}_{p}$ 는 요소 $i$ 의 각 축방향의 각가 속도, $[M]_{i j}$ 는 요소 $i$ 에 작용하는 각 축주변의 모멘트 이다.

\section{2 해석영역 및 해석조건}

본 연구에서는 Fig. 6에서 나타낸 바와 같이 감쇄율이 높은 두 종류의 마운드를 대상으로, 구조물을 구성하는 요소군을 원 형요소로 ${ }^{10}$ 가정하는 대신 요소에 주어지는 스프링계수, 점성계 수 및 마찰계수를 Table 2의 값을 기준으로 몬테카를로법을 사 용해서 랜덤하게 입력하는 것에 의해 요소 구성의 임의성을 표 현했다.

$\mathrm{VOF}$ 에 의한 파동장의 해석에서는 $\mathrm{DEM}$ 과의 연동 해석을 위 해 $\Delta t=1.0 \times 10^{-3} \mathrm{~s}$ 로 일정하게 설정하고, 천단 수심은 $2 \mathrm{~cm}$ 로 설정했다.10외력으꼬서는 C\&DMAStSURF와4 동일한 5 조건으로 주기 $1.2 \mathrm{~s}$, 파고 $0.12 \mathrm{~m}$ 의 파를 작용시켰다. 구조물 내부의 흐름 을 해석하기 위해서 마운드 구조물의 공극률을 前野 등(2006) 을 참고로 0.35 로 하고 항력계수와 관성력계수는 각각 0.5 와 1.5 로 했다. 또한, 양력계수에 대해서는 伊藤 등(2001)의 연구를 참 고로 0.5 로 했다.

점성감쇄계수는 수중에서의 거동임을 고려해서, 수속을 빠르 게 하기 위해 각각의 요소에 대해서 $\eta=2 \sqrt{m K}$ 의 값을 적용 해서 해석을 실시했다. 표에 표기되어 있는 값은 법선 방향에 대한 값이며 접선방향에 대해서는 법선방향 값의 $25 \%$ 를 적용 했다. 또한 유체력은 마운드를 구성하는 요소에만 작용시키고 지반요소는 마운드 요소의 움직임에 대응할 수 있도록 했다.

구조물은 유체력을 받아 단면이 변화하고 그 변화된 단면에 의해 파동장이 변화하므로 구조물의 단면변화와 파동장과의 상 호작용을 고려하는 것이 중요하다. 본 연구에서는 계산을 세 단 계로 나누어 피드백 해석을 실시했다. 즉, 초기 마운드 단면을 이용해서 계산한 유체력을 $\mathrm{DEM}$ 해석에 외력으로 작용시켜 요 소의 이동을 계산하고 단면을 수정, 변형된 마운드 단면을 이용 해서 유체력을 계산하는데 이와 같은 계산과정을 3 회 반복했다. 각 스텝 간격은 파랑의 3주기분인 3.6초로 했다. 그리고 $\mathrm{DEM}$ 해석에 있어서의 시간 간격 $\Delta t$ 는 $1.0 \times 10^{-5} s$ 로 했다. Fig. 7은 해석영역의 제원을 나타낸다.

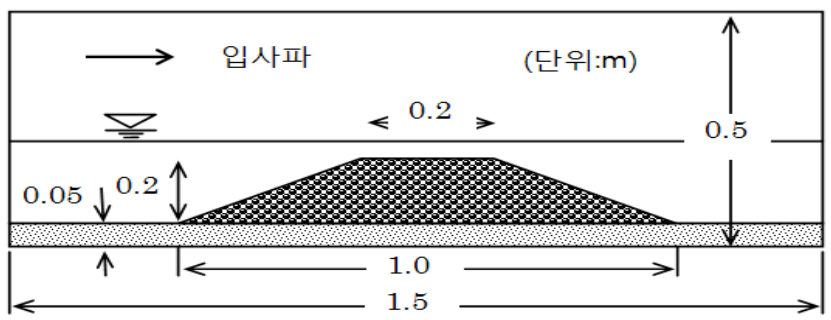

Fig. 7 Computation area
Table 2 Average values of input parameters

\begin{tabular}{|c|c|c|}
\hline $\begin{array}{c}\text { 스프링 계수 } \\
(\mathrm{N} / \mathrm{m})\end{array}$ & $\begin{array}{c}\text { 점성감쇄계수 } \\
(\mathrm{Ns} / \mathrm{m})\end{array}$ & $\begin{array}{c}\text { 마찰계수 } \\
\text { (degree) }\end{array}$ \\
\hline $1 \times 10^{4}$ & $\begin{array}{c}2 \sqrt{m K} \\
\text { 질량, } K \text { :스프링 계수 }\end{array}$ & 45 \\
\hline \multicolumn{2}{|c}{} \\
\hline
\end{tabular}

\section{3 해석결과}

Fig. 8은 각각의 지점에서의 모형실험에서 얻어진 파형과 $\mathrm{CADMAS}-\mathrm{SURF}$ 에 의해 얻어진 파형을 비교한 것이다. a)와 b)에서 수치해석에 의한 파형과 모형실험에 의한 파형이 거의 일치하는 결과가 나타났다. 지점 3 의 경우에 두 결과에 약간의 차이는 있으나 정성적으로 일치한다고 판단된다. 지점 3 에서 보 이는 약간의 차이는 설정한 마운드 내부의 공극률의 설정 차이 에 의한 것으로 추측된다.

Fig. 9의 a), b)는 입경 $2 \mathrm{~cm}$ 의 동일입경 요소로 구성된 마운 드의 단면변형 해석 결과이고 $\mathrm{c}), \mathrm{d}$ )는 입경 $2.6 \mathrm{~cm}$ 와 $1.5 \mathrm{~cm}$ 의 혼합 요소로 구성된 마운드의 단면변형 결과이다. Fig. 9 b)에 서 보면 초기 단면에 비해 마운드 천단부 전체에 걸쳐 침식이 발생되어 있고, 마운드 후방의 사면 상에 퇴적되어 있는 것을 알 수 있다. 실험 결과와 비교해 보면, 마운드 전방에서 침식해 사면에서 하부에 걸쳐 퇴적된 것은 일치하나, 모형실험에서는 마운드 후방 상부에서의 침식은 나타나지 않았다. 실험에 이용 된 사석의 경우, 입경의 편차가 크고 또한 타원 형태의 요소가 많아서 양력의 영향을 크게 받으므로 파력에 의해 쉽게 반대편 으로 운반되고 퇴적된 사석이 전도되지 않았지만, 계산에서는 이용된 요소가 원형요소이므로 반대편으로 운반된 요소가 전도 되어 하부까지 이동되었기 때문인 것으로 판단된다.

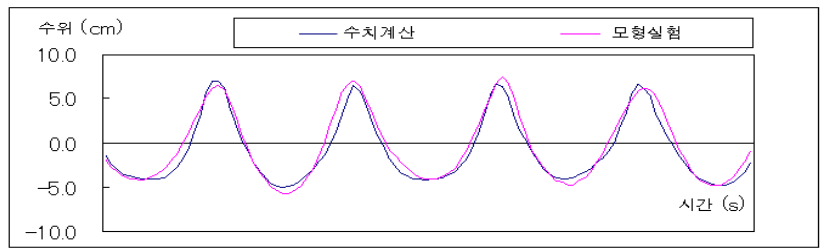

a) Point 1

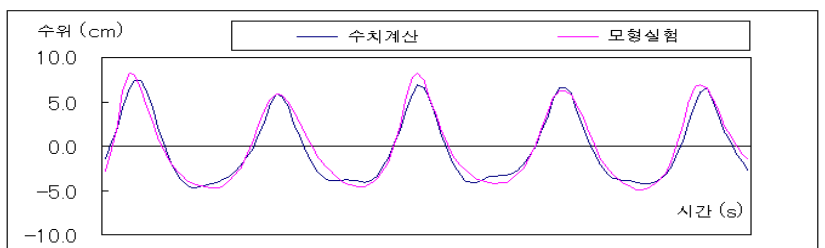

b) point 2

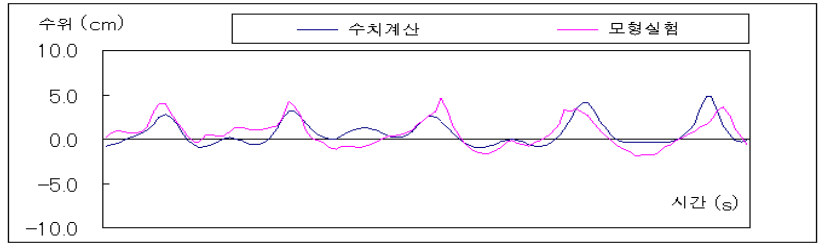

c) point 3

Fig. 8 Comparison of wave heights by numerical analysis and experiment 
그리고 Fig. 9 d)의 결과를 보면 마운드 양 상부가 침식되어 후방의 사면하부에 퇴적되어 있으며 침식의 정도는 마운드 전 방측이 많다. 마운드 천단 전체에서 침식이 발생하여 후방 사면 에서 하부에 걸쳐 퇴적되어 있는 것은 모형실험 및 수치해석 결과가 일치한다.

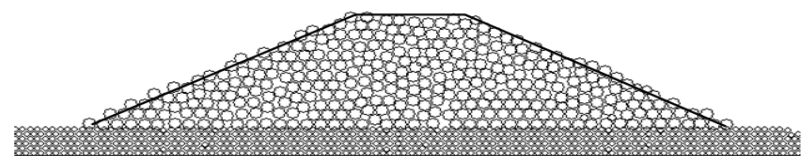

a) Incipient section(uniform size of $2 \mathrm{~cm}$ )

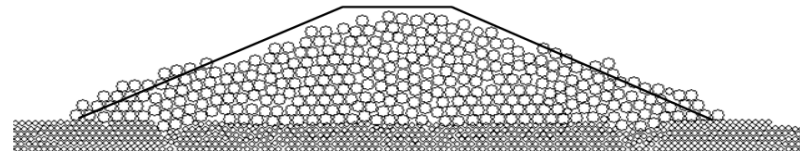

b) deformed section

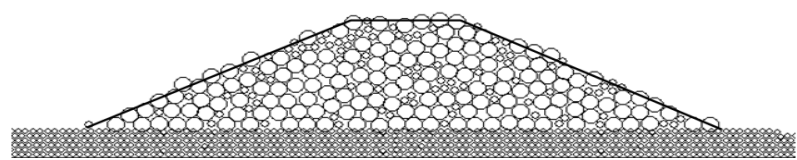

c) Incipient section(mixed sizes of $2.6 \mathrm{~cm}$ and $1.5 \mathrm{~cm}$ )

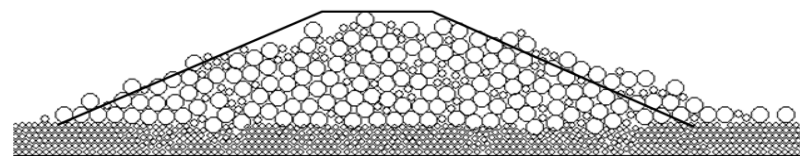

d) deformed section

Fig. 9 Results of numerical analysis

\section{4. 결 론}

본 연구에서는 혼합입경을 가진 요소로 구성된 마운드 구조 물의 파랑에 의한 파괴의 특성과 구조물 주변 파동장의 특성을 실험을 통해 명확히 함과 동시에 $\mathrm{VOF}$ 법과 $\mathrm{DEM}$ 을사용하여 수 치 계산을 실시하여 실험결과와 비교하는 것으로 그 타당성을 검토했다.

연구의 결과를 정리하면 다음과 같다.

1) 천단수심을 $5 \mathrm{~cm}$ 와 $2 \mathrm{~cm}$ 로 하고 요소를 평균입경 $2 \mathrm{~cm}$ 의 사석, 입경 $2.6 \mathrm{~cm}, 1.5 \mathrm{~cm}$ 의 혼합 요소 및 $2.9 \mathrm{~cm}, 2.6 \mathrm{~cm}$ 의 혼합 요소를 사용한 세 종류의 마운드를 구성하여 수리모형실험을 실시, 천단수심과 마운드 구조물을 구성하는 요소의 크기와 형 태에 의한 파괴, 변형 과정을 명확히 하고, 구조물 구성성분에 따라 파랑 감쇄율에 큰 차이가 있음을 확인했다.

2) $\mathrm{VOF}$ 와 DEM을 사용해 마운드 구조물의 단면변형을 계산 했다. 이 때, 실험결과와의 비교를 위해, 입경 $2 \mathrm{~cm}$ 의 동일 요소 모델과 입경 $2.6 \mathrm{~cm}, 1.5 \mathrm{~cm}$ 혼합입경요소 모델의 두 종류를 구 성해 해석을 실시했다. 또한 몬테카를로법을 사용해 계수를 임 의로 입력하는 것으로 요소구성의 다양성을 표현했다. 그 결과 얻어진 단면변형의 형태가 실험결과와 일치하는 것을 확인했으 며 해석 모델의 타당성이 입증되었다.

\section{후 기}

이 논문은 2008년도 (재)산학협동재단의 지원에 의해 연구되 었습니다.

\section{참고문헌}

[1] 荒木進步, 柳原哲也, 出口一郎(2003), “3 次元個別要素法 による捨石潛堤の変形予測の試み”, 海岸工學論文集, 土 木學會, Vol.50, pp.831-835.

[2] 伊藤一呚, 樋口雄一, 東江隆夫, 勝井秀博(2001), “個別要 素法に基づく捨石のランダム性を考慮した潛堤の変形予測 手法”, 海岸工學論文集, 土木學會, Vol.48, pp.806-810.

[3] 金美錦, 黑岩正光, 西村强, 松原雄平(2007), “VOF-DEM モデルを用いた混合粒緟砂礫から構成される捨石潛堤擧動 解析に關する研究”, 海洋開發論文集, Vol.23, pp.913-918.

[4] 椹木亨(1991), 波と漂砂と構造物, 技報堂出版, pp.203-213.

[5] 高山知司, 高橋通夫(2006), “ケーソンを單一要素とした個 別要素法による混成堤の擧動計算”，海岸工學論文集，土木 學會 Vol.53, pp.841-845.

[6] 土木學會(1985), 水理公式集，土木學會編，pp.523.

[7] 藤井直樹, 興野俊也, 大熊義夫(2001), “個別要素法による ケーソン防波堤の滑動計算”，海岸工學論文集，土木學 會, Vol.48, pp.801-805.

[8] 前野詩朗, 小川誠, Bierawski,L.G.(2006), “VOF-DEMFEM 連成モデルによる潛堤の擧動解析“，海岸工學論文 集，土木學會，Vol.53，pp.886-890.

[9] Cundall, P. A.(1971), “A computer model for simulating progressive", large-scale movements in blocky rock systems, Symposium on rock mechanics, Nancy, Vol. 2, pp.129-136.

[10] Hirt, C. W. and Nichols, B. D.(1981), "Volume of fluid method for the dynamics of free boundaries", J. Comp. Phys., Vol.39, pp.201-225.

원고접수일 : 2010년 4월 9일 심사완료일 : 2010년 7월 12일 원고채택일 : 2010년 7월 21일 